\title{
Antimicrobial activities of the methanol extract and compounds from Artocarpus communis (Moraceae)
}

\author{
Victor Kuete ${ }^{1 *}$, Patrick Y Ango ${ }^{2}$, Ghislain W Fotso ${ }^{3}$, Gilbert DWF Kapche ${ }^{2 *}$, Jean P Dzoyem ${ }^{1}$, Arlette G Wouking ${ }^{3}$, \\ Bonaventure T Ngadjui ${ }^{3}$ and Berhanu M Abegaz ${ }^{4}$
}

\begin{abstract}
Background: Artocarpus communis is used traditionally in Cameroon to treat several ailments, including infectious and associated diseases. This work was therefore designed to investigate the antimicrobial activities of the methanol extract (ACB) and compounds isolated from the bark of this plant, namely peruvianursenyl acetate $C(\mathbf{1})$, $\alpha$-amyrenol or viminalol (2), artonin E (4) and 2-[(3,5-dihydroxy)-(Z)-4-(3-methylbut-1-enyl)phenyl]benzofuran-6-ol (5).
\end{abstract}

Methods: The liquid microdilution assay was used in the determination of the minimal inhibitory concentration $(\mathrm{MIC})$ and the minimal microbicidal concentration (MMC), against seven bacterial and one fungal species.

Results: The MIC results indicated that ACB as well as compounds $\mathbf{4}$ and $\mathbf{5}$ were able to prevent the growth of all tested microbial species. All other compounds showed selective activities. The lowest MIC value of $64 \mathrm{\mu g} / \mathrm{ml}$ for the crude extract was recorded on Staphylococcus aureus ATCC 25922 and Escherichia coli ATCC 8739. The corresponding value of $32 \mathrm{\mu g} / \mathrm{ml}$ was recorded with compounds $\mathbf{4}$ and $\mathbf{5}$ on Pseudomonas aeruginosa PA01 and compound $\mathbf{5}$ on E. coli ATCC 8739, their inhibition effect on P. aeruginosa PA01 being more than that of chloramphenicol used as reference antibiotic.

Conclusion: The overall results of this study provided supportive data for the use of $A$. communis as well as some of its constituents for the treatment of infections associated with the studied microorganisms.

\section{Background}

Artocarpus comminis J.R. \& G. Forst., commonly known as breadfruit tree because of the "bread-like texture" of its edible fruits, is an equatorial lowland species of flowering tree in the mulberry family (Moraceae) that grows best below elevations of $650 \mathrm{~m}$ [1]. Numbers of medicinal uses are assigned to plants of the genus Artocarpus worldwide. This includes treatments of cardiovascular diseases (yellow leaf decoction of A. communis in Bahamas, Haiti, Trinidad and West Indies), chest pain and vomiting from heart problems (Artocarpus spp. in South Pacific), boils, abscess, and skin infections (leaf ash,

\footnotetext{
* Correspondence: kuetevictor@yahoo.fr; dkapche2002@yahoo.com 'Department of Biochemistry, Faculty of Science, University of Dschang, Cameroon

'Department of Chemistry, Higher Teachers' Training College, University of Yaoundé I, Cameroon

Full list of author information is available at the end of the article
}

macerated root, or latex of Artocarpus spp. sap in Dominican Republic, Haiti, Hawai'i, Malaya, Java, Samoa, Tahiti and Tonga), cracked-skin and dermatosis (A. communis in Hawai'i), burns (A. communis in Haiti), rashes (sap of Artocarpus spp. in Tahiti, Tonga); stomach pain (bark of Artocarpus spp. diluted latex in Samoa, Solomon Islands and Tonga), diarrhea or dysentery (diluted latex or roots boiled of Artocarpus spp. in Borneo, Java, Pacific Islands and Samoa), diabetes (yellow leaf as tea of Artocarpus spp. in Trinidad, West Indies), headache (leaves of $A$. communis in Bahamas, bark in Samoa and Pacific Islands, toothache (toasted flowers of $A$. communis and A. integra in Java and Malaya), thrush (crushed leaf buds and latex of $A$. communis on tongue in Bahamas, Trinidad and Pacific Islands), eye problems (A. communis leaf or petiole juice in Futuna and Samoa), ear infections (leaves juice or
C Biomed Central

() 2011 Kuete et al; licensee BioMed Central Ltd. This is an Open Access article distributed under the terms of the Creative Commons Attribution License (http://creativecommons.org/licenses/by/2.0), which permits unrestricted use, distribution, and reproduction in any medium, provided the original work is properly cited. 
diluted latex in Pacific Islands), herpes infections (A. communis in Amboina), fever (A. communis leaves in Bahamas, Malaya and Samoa), enlarged spleen (A. communis in Java) [2]. In Cameroon, the fruits of A. communis are used as food; other parts of the plants are traditionally used to treat headache, infectious and associated diseases such as toothache, eye problems, ear infections, herpes, enlarged spleen, sprains, contusions, swelling [3-5]. Some scientific evidences of the bioactivity of A. communis were reported on the extract or isolated compounds [6-9]. However, few reports are related to the antimicrobial activity of this taxon. The present work was therefore designed to investigate the antibacterial and anticandicidal activities of the methanol extract and compounds isolated from the stem bark of Artocarpus communis.

\section{Methods}

\section{Plant material}

The roots of Artocarpus communis J.R. \& G. Forst. were collected in Nkolbisson, Center region of Cameroon in March 2010. The plant was identified by Mr. Victor Nana of the National herbarium (Yaoundé, Cameroon) where a voucher specimen was deposited under the reference number 43982/HNC.

\section{Extraction and purification}

The air dried and powdered stem bark (700 g) were extracted with methanol $(\mathrm{MeOH})$ for $48 \mathrm{~h}$ at room temperature. The extract was then concentrated under reduced pressure to give $170 \mathrm{~g}$ of a brown residue that constituted the crude extract (ACB). Part of FPR (150 g) was submitted to silica gel $60(0.04-0.063 \mathrm{~mm}, 120 \mathrm{~g})$ vacuum column chromatography using as eluent, hexane, hexane/ $\mathrm{CHCl}_{3}$ 1:1 mixture, $\mathrm{CHCl}_{3}$ and $\mathrm{CHCl}_{3} / \mathrm{MeOH}$. Fractions of $500 \mathrm{ml}$ each were collected, concentrated under vacuum and pooled on the basis of the thin layer chromatography (TLC) analysis in six fractions, A-F. Peruvianursenyl acetate $\mathrm{C}_{32} \mathrm{H}_{52} \mathrm{O}_{2}(1 ; 4.4 \mathrm{mg} ; \mathrm{m} / \mathrm{z}$ 468.40; amorphous powder) [10] and $\alpha$-amyrenol $\mathrm{C}_{30} \mathrm{H}_{50} \mathrm{O}(2$; $70.3 \mathrm{mg} ; \mathrm{m} / \mathrm{z} 426.99$; amorphous powder) [11] were directly obtained from fractions eluted with hexane $/ \mathrm{CHCl}_{3}$ 7:3. Sitosterol 3-O- $\beta$ - $D$-glucopyranoside $\mathrm{C}_{17} \mathrm{H}_{18} \mathrm{O}_{4}$ (3; 5.5 $\mathrm{mg} ; \mathrm{m} / \mathrm{z} 286.12$; whitish powder, m.p. $130-145^{\circ} \mathrm{C}$ ) [12] was directly obtained from fractions eluted with $\mathrm{CHCl}_{3} / \mathrm{MeOH}$ 8:2. Fraction E (10.0 g) obtained with $\mathrm{CHCl}_{3}$ was subjected to $\mathrm{CC}$ (silica gel 60, $50 \mathrm{~g}$ ) and eluted with $\mathrm{CHCl}_{3}-\mathrm{MeOH}$ mixture of increasing polarity to give 7 sub-fractions $\left(\mathrm{E}_{1}\right.$ $\left.\mathrm{E}_{7}\right)$. Sub-fraction $\mathrm{E}_{1}\left(\mathrm{CHCl}_{3}\right.$ to $\mathrm{CHCl}_{3}-\mathrm{MeOH}$ 97.5:2.5) and $\mathrm{E}_{4}\left(\mathrm{CHCl}_{3}-\mathrm{MeOH} 95: 5\right.$ to $\left.90: 10\right)$ were repeatedly filtered through Sephadex $\mathrm{LH}-20\left(\mathrm{CHCl}_{3}-\mathrm{MeOH} 7: 3\right)$ to yield artonin $\mathrm{E} \mathrm{C}_{25} \mathrm{H}_{24} \mathrm{O}_{7}(4 ; 10.0 \mathrm{mg}, \mathrm{m} / \mathrm{z} 436.14$; yellow crystals, m.p.: $\left.255-257^{\circ} \mathrm{C}\right)$ [13] and 2-[(3,5-dihydroxy)-(Z)4-(3-methylbut-1-enyl)phenyl]benzofuran-6-ol $\mathrm{C}_{19} \mathrm{H}_{18} \mathrm{O}_{4}$
(5; $12.8 \mathrm{mg} ; \mathrm{m} / \mathrm{z}$ 310.0; yellow oil) [14]. The chemical structures of the isolated compounds are illustrated in Figure 1.

\section{General procedure}

Aluminum sheet pre-coated with silica gel $60 F 254 \mathrm{~nm}$ (Merck) was used for thin layer chromatography; The spots were visualized using both ultraviolet light (254 and $366 \mathrm{~nm}$ ) and $50 \% \mathrm{H}_{2} \mathrm{SO}_{4}$ spray reagent. NMR spectra were recorded on a Bruker Avance 300 at $300 \mathrm{MHz}$ $\left({ }^{1} \mathrm{H}\right)$ and $75 \mathrm{MHz}$ and Bruker Avance 600 at $600 \mathrm{MHz}$ $\left({ }^{1} \mathrm{H}\right)$ and $150 \mathrm{MHz}\left({ }^{13} \mathrm{C}\right)$, with the residual solvent peaks as internal references. The melting point (m.p.) were determined using a Kofler microhot stage apparatus. Mass spectra were recorded with API QSTAR pulsar mass spectrometer. The structures of the compounds were confirmed by comparing with reference data from available literature.

\section{Antimicrobial assays \\ Microbial strains and culture media}

The studied microorganisms included reference strains of Providencia stuartii, Pseudomonas aeruginosa, Klebsiella pneumoniae, Staphylococcus aureus, Salmonella typhi, Escherichia coli, Candida albicans obtained from the American Type Culture Collection. They were maintained on agar slant at $4^{\circ} \mathrm{C}$ and sub-cultured on a fresh appropriate agar plates $24 \mathrm{~h}$ prior to any antimicrobial test. Nutrient Agar and Sabouraud Glucose Agar were used for the activation of bacteria and fungi respectively. The Mueller Hinton Broth (MHB) was used for the MIC and MMC determinations. The Mueller Hinton Agar (MHA) was also used for the determination of the MMC on these species [15].

\section{Chemicals for antimicrobial assay}

Chloramphenicol (Sigma-Aldrich, St. Quentin Fallavier, France) and Nystatin (Sigma-Aldrich) were used as reference antibiotics (RA) respectively against bacteria and Candida albicans. $p$-Iodonitrotetrazolium chloride

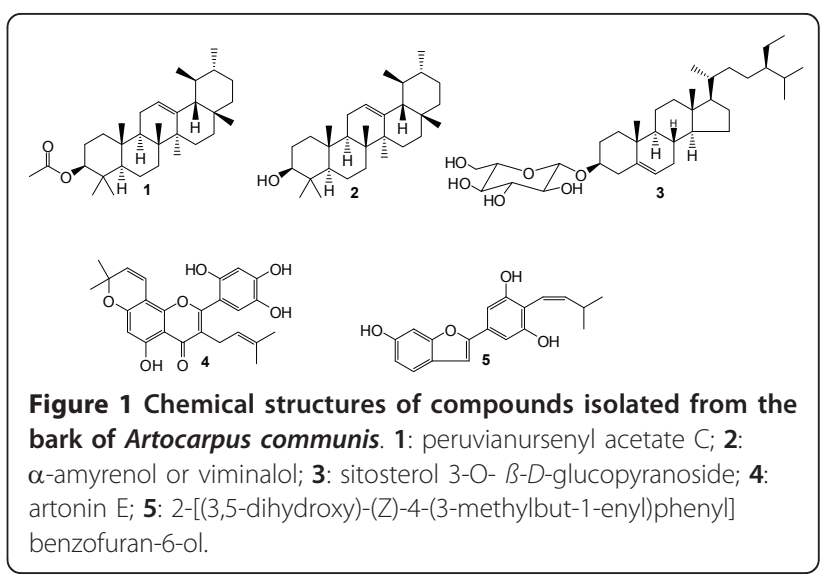


(INT, Sigma-Aldrich) was used as microbial growth indicator [16,17].

\section{MIC and MMC determinations}

The MIC determinations on bacteria and C. albicans were conducted using rapid INT colorimetric assay according to described methods $[16,17]$ with some modifications. Briefly, the test sample was first of all dissolved in 10\% (v/v) DMSO/MHB to give a final concentration of $512 \mu \mathrm{g} /$ $\mathrm{ml}$ and serially diluted twofold to obtain concentration ranges. $100 \mu \mathrm{l}$ of each concentration was added in a well (96-well microplate) containing $95 \mu \mathrm{l}$ of MHB and $5 \mu \mathrm{l}$ of inoculum (standardized at $1.5 \times 10^{6} \mathrm{CFU} / \mathrm{ml}$ by adjusting the optical density to 0.1 at $600 \mathrm{~nm}$ SHIMADZU UV-12001 spectrophotometer) [18]. The final concentration of DMSO in the well was less than 3\% (preliminary analyses with 3\% (v/v) DMSO do not alter the growth of the test organisms). The negative control well consisted of $195 \mu \mathrm{l}$ of $\mathrm{MHB}$ and $5 \mu \mathrm{l}$ of the standard inoculum [19]. The plates were covered with a sterile plate sealer, then agitated to mix the contents of the wells using a plate shaker and incubated at $37^{\circ} \mathrm{C}$ for $24 \mathrm{~h}$. The assay was repeated three times in triplicate. The MIC of samples was detected following addition $(40 \mu \mathrm{l})$ of $0.2 \mathrm{mg} / \mathrm{ml} p$-iodonitrotetrazolium chloride and incubation at $37^{\circ} \mathrm{C}$ for $30 \mathrm{~min}[16,17]$. Viable microorganisms reduced the yellow dye to a pink colour. MIC was defined as the lowest sample concentration that prevented this change and exhibited complete inhibition of bacterial growth. For the determination of MMC, a portion of liquid $(5 \mu \mathrm{l})$ from each well that showed no change in colour was plated on MHA and incubated at $37^{\circ} \mathrm{C}$ for $24 \mathrm{~h}$. The lowest concentration that yielded no growth after this sub-culturing was taken as the MMC [20].

\section{Results and discussion}

The structures of the isolated compounds were established using spectroscopic analysis, especially, NMR spectra in conjunction with 2D experiments, COSY, HMQC, $\mathrm{HMBC}$, and direct comparison with published information and with authentic specimens obtained in our research group for some cases. The compounds isolated from the stem bark of $A$. communis (Figure 1) were identified as peruvianursenyl acetate $C(\mathbf{1}), \alpha$-amyrenol or viminalol (2), sitosterol 3-O- $\beta$ - $D$-glucopyranoside (3), artonin E (4) and 2-[(3,5-dihydroxy)-(Z)-4-(3-methylbut-1-enyl)phenyl] benzofuran-6-ol (5). Numbers of terpenoids isolated from A. communis such as compounds $\mathbf{2}$ and $\mathbf{3}$ are ubiquitous in plant kingdom. The flavonoid, Artonin $\mathrm{E}$ was previously reported in other Artocapus species, A. kemando, A. nobilis and $A$. rigida $[13,21,22]$ meanwhile the arylbenzofuran, 2[(3,5-dihydroxy)-(Z)-4-(3-methylbut-1-enyl)phenyl]benzofuran-6-ol was reported in Artocarpus heterophyllus [23]. In the present work, the crude extract as well as most of the compounds isolated from the bark of A. communis were tested for their antibacterial activities and against C. albicans. The results are reported in Tables 1 and 2 .

The MIC results (Table 1 ) indicated that the crude extract (ACB) as well as compounds $\mathbf{4}$ and $\mathbf{5}$ inhibited the growth of all tested microbial species. All other compounds showed selective activities, their inhibitory effects being noted on 3 of the 8 (37.5\%) tested organisms for compound 1 and 2 . The lowest MIC value $(64 \mu \mathrm{g} / \mathrm{ml})$ for the crude extract was recorded on two of the tested microbial species namely $S$. aureus and E. coli ATCC8739. Phytochemicals are routinely classified as antimicrobials on the basis of susceptibility tests that produce MIC) in the range of 100 to $1000 \mathrm{mg} / \mathrm{mL}$ [24]. Their activity is considered to be significant if MIC values are below 100 $\mu \mathrm{g} / \mathrm{ml}$ for crude extract and $10 \mu \mathrm{g} / \mathrm{ml}$ for pure compounds [25]. Therefore, the activity recorded herein can be considered as important, when considering the cutoff point 100 $\mu \mathrm{g} / \mathrm{ml}$ required for MIC values of plant extracts with significant activity [25]. Nevertheless, moderate activities

Table $1 \mathrm{MIC}(\mu \mathrm{g} / \mathrm{ml})$ of the crude extract, compounds isolated from the bark of Artocarpus communis and reference antibiotics on the studied microbial species

\begin{tabular}{|c|c|c|c|c|c|c|c|c|}
\hline \multirow[t]{3}{*}{ Tested samples $^{a}$} & \multicolumn{8}{|c|}{ Microorganisms, strains and MIC $(\mu \mathrm{g} / \mathrm{ml})^{\mathrm{b}}$} \\
\hline & \multirow[b]{2}{*}{ P. stuartii } & \multirow[b]{2}{*}{$P$. aeruginosa } & \multirow[b]{2}{*}{ K. pneumoniae } & \multirow[b]{2}{*}{ S.aureus ATCC25922 } & \multirow[b]{2}{*}{ S. typhi ATCC6539 } & \multicolumn{2}{|c|}{ E. coli } & \multirow[b]{2}{*}{ C. albicans } \\
\hline & & & & & & & & \\
\hline & ATCC29916 & PA01 & ATCC11296 & & & AG100 & ATCC 8739 & W3100 \\
\hline$A C B$ & 256 & 256 & 128 & 64 & 128 & 256 & 64 & 128 \\
\hline 1 & - & - & 256 & 512 & - & - & - & 512 \\
\hline 2 & - & - & 512 & 512 & - & - & 512 & - \\
\hline 4 & 512 & 32 & 128 & 256 & 64 & 512 & 64 & 512 \\
\hline 5 & 128 & 32 & 256 & 256 & 64 & 64 & 32 & 128 \\
\hline RA & 32 & 64 & 4 & 4 & 4 & 4 & 4 & 16 \\
\hline
\end{tabular}

${ }^{a}$ The tested samples were the methanol extract from the bark of Artocarpus communis (ACB), isolated compounds, 1 : peruvianursenyl acetate $C ;$ : $\alpha$-amyrenol or viminalol; 3: sitosterol 3-O- B-D-glucopyranoside; 4: artonin E; 5: 2-[(3,5-dihydroxy)-(Z)-4-(3-methylbut-1-enyl)phenyl]benzofuran-6-ol and chloramphenicol (for bacteria) and nystatin (for $C$. albicans) used as the reference antibiotics (RA).

${ }^{\mathrm{b}}$ The tested microorganisms were Providencia stuartii (P. stuartii); Pseudomonas aeruginosa (P. aeruginosa); Klebsiella pneumoniae (K. pneumoniae); Staphylococcus aureus (S. aureus); Salmonella typhi (S. typhi); Escherichia coli (E. coli); Candida albicans (C. albicans). (-): MIC >512 $\mu \mathrm{g} / \mathrm{ml}$; (nd): not determined. 
Table 2 MMC $(\mu \mathrm{g} / \mathrm{ml})$ of the crude extract, compounds isolated from the bark of Artocarpus communis and reference antibiotics on the studied microbial species

\begin{tabular}{|c|c|c|c|c|c|c|c|c|}
\hline \multirow[t]{3}{*}{ Tested samples ${ }^{\mathrm{a}}$} & \multicolumn{8}{|c|}{ Microorganisms, strains and MMC $(\mu \mathrm{g} / \mathrm{ml})^{\mathrm{b}}$} \\
\hline & \multirow[b]{2}{*}{ P. stuartii } & \multirow[b]{2}{*}{$P$. aeruginosa } & \multirow[b]{2}{*}{ K. pneumoniae } & \multirow[b]{2}{*}{ S.aureus ATCC25922 } & \multirow[b]{2}{*}{ S. typhi ATCC6539 } & \multicolumn{2}{|c|}{ E. coli } & \multirow[b]{2}{*}{ C. albicans } \\
\hline & & & & & & & & \\
\hline & ATCC29916 & PA01 & ATCC11296 & & & AG100 & ATCC 8739 & W3100 \\
\hline$A C B$ & $>512$ & 512 & 256 & 256 & 256 & 512 & 256 & 256 \\
\hline 1 & - & - & 256 & $>512$ & $>512$ & - & - & $>512$ \\
\hline 2 & - & - & $>512$ & $>512$ & - & - & $>512$ & nd \\
\hline 4 & $>512$ & 128 & 256 & 512 & 128 & $>512$ & 128 & $>512$ \\
\hline 5 & 256 & 64 & 512 & 512 & 128 & 256 & 64 & 256 \\
\hline RA & 64 & 128 & 8 & 8 & 8 & 8 & 8 & 32 \\
\hline
\end{tabular}

${ }^{a}$ The tested samples were the methanol extract from the bark of Artocarpus communis (ACB), isolated compounds, 1: peruvianursenyl acetate $C ;$ : $\alpha$-amyreno or viminalol; 3: sitosterol 3-O- B-D-glucopyranoside; 4: artonin E; 5: 2-[(3,5-dihydroxy)-(Z)-4-(3-methylbut-1-enyl)phenyl]benzofuran-6-ol and chloramphenicol (for bacteria) and nystatin (for C. albicans) used as the reference antibiotics (RA).

${ }^{b}$ The tested microorganisms were Providencia stuartii (P. stuartii); Pseudomonas aeruginosa (P. aeruginosa); Klebsiella pneumoniae (K. pneumoniae); Staphylococcus aureus (S. aureus); Salmonella typhi (S. typhi); Escherichia coli (E. coli); Candida albicans (C. albicans). (-): MIC >512 $\mu \mathrm{g} / \mathrm{ml}$; (nd): not determined.

[25] were recorded with compounds 4 and 5 on three (37.5\%) and four (50\%) of the studied microorganisms respectively. $P$. aeruginosa is an important nosocomial pathogen highly resistant to commonly used antibiotics, causing a wide spectrum of infections and leading to substantial morbidity and mortality [26]. The lowest MIC value of $32 \mu \mathrm{g} / \mathrm{ml}$ was recorded with compounds $\mathbf{4}$ and $\mathbf{5}$ on $P$. aeruginosa and compound $\mathbf{5}$ on E. coli ATCC8739, highlighting some medicinal potential for the two compounds, as the activity on $P$. aeruginosa was better than that of chloramphenicol.

However if considered a more flexible stringent criteria indicating that extracts having activities with MIC values below $8 \mathrm{mg} / \mathrm{ml}$ [27] are considered to possess some antimicrobial activity and natural products with MIC values below $1 \mathrm{mg} / \mathrm{ml}$ are considered noteworthy $[28,29]$, the overall activity recorded therefore with the extracts, compounds $\mathbf{4}$, and $\mathbf{5}$ could be considered as important, highlighting the antimicrobial potency of A. communis. However, the tested samples were less active than chloramphenicol and nystatin used as reference antibiotic on most of the microbial strains. The results of Table 2 showed detectable MMC values for some of the studied samples on the tested microbial strains. When analysing carefully the MIC and MMC results for the crude extract, compounds 4 and 5, it can be noted that MMC/MIC ratios lower than 4 were obtained with these samples on most of the tested microbial species, suggesting that a killing effects could be expected [30]. However, all MMC values obtained were greater than the MICs. It can also be noted the reference antibiotics were in most of the case more active than all studied samples, except on $P$. aeruginosa PA01 where the MIC values obtained with compounds 4 and 5 were two time lower.
To the best of our knowledge, the antibacterial and anti-candicidal activities of the bark extract of A. communis as well as that of compounds $\mathbf{4}$, and $\mathbf{5}$ are being reported for the first time. However, the antimicrobial activity of this plant might be due to the presence of both antibacterial and anticandicidal compounds as demonstrated in the present study. The antimicrobial activity of sitosterol-3-O- $\beta$ - $D$-glucopyranoside (compound 3) was reported [31,32], and this compound was not tested again in the present work. It's activities were moderate, but sitosterol-3-O- $\beta$ - $D$-glucopyranoside as well as the tested compounds might contribute to the overall activity observed with the extract of $A$. communis.

\section{Conclusion}

Finally, the present investigation provides supportive data for the use of A. communis as well as some of its constituents for the treatment of infections associated with the studied microorganisms. However, this will be confirmed with further pharmacological (in vivo activity, bioavailability) and toxicological studies (acute and subacute toxicities using animal models).

\section{Acknowledgements}

The Chemistry Department of the University of Botswana is acknowledged for providing research facilities. AYP is grateful to the Third World Academic of Science (TWAS) for travel grant and to the Network of Analytical and Bioassay Services in Africa (NABSA) for a 3-months maintenance grant to the University of Botswana.

\section{Author details}

'Department of Biochemistry, Faculty of Science, University of Dschang, Cameroon. 'Department of Chemistry, Higher Teachers' Training College, University of Yaoundé I, Cameroon. ${ }^{3}$ Department of Organic Chemistry, Faculty of Science, University of Yaoundé I, P.O. Box 812, Yaoundé, Cameroon. ${ }^{4}$ Department of Chemistry, Faculty of Science, University of Botswana, Private Bag 00704, Gaborone, Botswana. 


\section{Authors' contributions}

VK and PYA carried out the study and wrote the manuscript; GDWFK, BMA and BTN supervised the work and the manuscript writting. JPD and AGW contributed to the manuscript corrections and editing. All authors read and approved the final manuscript.

\section{Competing interests}

The authors declare that they have no competing interests.

Received: 11 February 2011 Accepted: 25 May 2011

Published: 25 May 2011

\section{References}

1. Ragone D: Artocarpus altilis (breadfruit): Moraceae (mulberry family) 2006 [http://www.agroforestry.net/tti/A.altilis-breadfruit.pdf], Accessed on December 08, 2010.

2. Medicine at your feet plants and food. 2010 [http://www. medicineatyourfeet.com], http://www.medicineatyourfeet.com/ artocarpuscommunis.html.

3. Leonard DB: Medicine at your Feet: Healing Plants of the Hawaiian Kingdom Pipturus spp. (Mämaki). 1998 [http://www.medicineatyourfeet. com/Pipturus_spp.pdf], Accessed on November 12, 2010.

4. Boyom FF, Kemgne EM, Tepongning R, Ngouana V, Mbacham WF, Tsamo E, Amvam Zollo PH, Gut J, Rosenthal PJ: Antiplasmodial activity of extracts from seven medicinal plants used in malaria treatment in Cameroon. $J$ Ethnopharmacol 2009, 123:483-488.

5. Kuete V, Efferth T: Cameroonian medicinal plants: Pharmacology and derived natural products. Front Pharmacol 2010, 1:123

6. Weng JR, Chan SC, Lu YH, Lin HC, Ko HH, Lin CN: Antiplatelet prenylflavonoids from Artocarpus communis. Phytochemistry 2006, 67:824-829

7. Adewole SO, Ojewole JAO: Artocarpus Communis Forst. Root-Bark Aqueous Extract- and Streptozotocin-Induced Ultrastructural and Metabolic Changes in Hepatic Tissues of Wistar Rats. Afr J Tradit Complement Altern Med 2007, 4:397-410.

8. Lotulung PD, Fajriah S, Hanafi M, Filaila E: Identification of cytotoxic compound from Artocarpus communis leaves against P-388 cells. Pak J Biol Sci 2008, 11:2517-2520.

9. Lin JA, Fang SC, Wu CH, Huang SM, Yen GC: Anti-inflammatory effect of the 5,7,4'-trihydroxy-6-geranylflavanone isolated from the fruit of Artocarpus communis in S100B-induced human monocytes. J Agric Food Chem 2011, 59:105-111.

10. Ali M, Ravinder E, Ramachandram R: New ursane-type triterpenic esters from the stem bark of Thevetia peruviana. Pharmazie 2000, 55:385-389.

11. Singh T, Bhakuni RS: A new euphane triterpene and a lipid constituent from the bark of Boswellia serrata. J Indian Chem Soc 2006, 83:588-590.

12. Wright LC, Shimizu S, Smith DG, Walter JA, Idler D, Khalil W: Identification of C-24 alkyl epimers of marine sterols by ${ }^{13} \mathrm{C}$ nuclear magnetic resonance spectroscopy. Can J Chem 1978, 56:1898-1903.

13. Suhartati $T$, Yandri Hadi S: The bioactivity test of artonin $E$ from the bark of Artocarpus rigida Blume. Eur I Sci Res 2008, 23:330-337.

14. Zong-Ping Z, Sibao C, Shiyun W, Xia-Chang, Ka-Wing C, Jia-Jun W, Dajiang Y, Mingfu W: Chemical components and tyrosinase inhibitors from the twigs of Artocarpus heterophyllus. J Agric Food Chem 2009, 57:6649-6655.

15. Kuete V, Kamga J, Sandjo LP, Ngameni B, Poumale HM, Ambassa P, Ngadjui BT: Antimicrobial activities of the methanol extract, fractions and compounds from Ficus polita Vahl. (Moraceae). BMC Complement Altern Med 2011, 11:6.

16. Eloff JN: A sensitive and quick microplate method to determine the minimal inhibitory concentration of plant extracts for bacteria. Planta Med 1998, 64:711-713.

17. Mativandlela SPN, Lall N, Meyer JJM: Antibacterial, antifungal and antitubercular activity of (the roots of) Pelargonium reniforme (CURT) and Pelargonium sidoides (DC) (Geraniaceae) root. S Afr J Bot 2006, 72:232-237.

18. Tereschuk ML, Riera MVQ, Castro GR, Abdala LR: Antimicrobial activity of flavonoid from leaves of Tagetes minuta. J Ethnopharmacol 1997, 56:227-232.
19. Zgoda JR, Porter JR: A convenient microdilution method screening natural products against bacteria and fungi. Pharmaceut Biol 2001, 39:221-225.

20. Kuete V, Ngameni B, Fotso Simo CC, Kengap Tankeu R, Tchaleu Ngadjui B, Meyer JJM, Lall N, Kuiate JR: Antimicrobial activity of the crude extracts and compounds from Ficus chlamydocarpa and Ficus cordata (Moraceae). J Ethnopharmacol 2008, 120:17-24

21. Seo EK, Lee D, Shin YG, Chai HB, Navarro HA, Kardono LB, Rahman I, Cordell GA, Farnsworth NR, Pezzuto JM, Kinghorn AD, Wani MC, Wall ME: Bioactive prenylated flavonoids from the stem bark of Artocarpus kemando. Arch Pharm Res 2003, 26:124-127.

22. Jayasinghe UL, Samarakoon TB, Kumarihamy BM, Hara N, Fujimoto Y: Four new prenylated flavonoids and xanthones from the root bark of Artocarpus nobilis. Fitoterapia 2008, 79:37-41.

23. Zheng ZP, Chen S, Wang S, Wang XC, Cheng KW, Wu JJ, Yang D, Wang M: Chemical components and tyrosinase inhibitors from the twigs of Artocarpus heterophyllus. J Agric Food Chem 2009, 57:6649-6655.

24. Simões M, Bennett RN, Rosa EA: Understanding antimicrobial activities of phytochemicals against multidrug resistant bacteria and biofilms. Nat Prod Rep 2009, 26:746-757.

25. Kuete V: Potential of Cameroonian plants and derived-products against microbial infections: A review. Planta Med 2010, 76:1-13.

26. Cardoso O, Alves AF, Leitao RM: Antimicrobial susceptibility among Pseudomonas aeruginosa. Int J Infect Dis 2008, 12:e111.

27. Fabry W, Okemo PO, Ansorg R: Antibacterial activity of East African medicinal plants. J Ethnopharmacol 1998, 60:79-84

28. Gibbons S: Anti-staphylococcal plant natural products. Nat Prod Rep 2004, 21:263-277.

29. Rios JL, Recio MC: Medicinal plants and antimicrobial activity. J Ethnopharmacol 2005, 100:80-84

30. Carbonnelle B, Denis F, Marmonier A, Pinon G, Vague R: Bactériologie médicale: Techniques usuelles. SIMEP, Paris; 1987.

31. Kuete V, Eyong KO, Beng VP, Folefoc GN, Hussain H, Krohn K, Nkengfack AE, Saeftel M, Sarite SR, Hoerauf A: Antimicrobial activity of the methanolic extract and compounds isolated from the stem bark of Newbouldia laevis Seem. (Bignoniaceae). Pharmazie 2007, 62:552-556

32. Manríquez-Torres J, Zúñiga-Estrada A, González-Ledesma M, TorresValencia JM: The Antibacterial Metabolites and Proacacipetalin from Acacia cochliacantha. J Mex Chem Soc 2007, 51:228-231.

\section{Pre-publication history}

The pre-publication history for this paper can be accessed here: http://www.biomedcentral.com/1472-6882/11/42/prepub

doi:10.1186/1472-6882-11-42

Cite this article as: Kuete et al:: Antimicrobial activities of the methanol extract and compounds from Artocarpus communis (Moraceae). BMC Complementary and Alternative Medicine 2011 11:42.

\section{Submit your next manuscript to BioMed Central and take full advantage of:}

- Convenient online submission

- Thorough peer review

- No space constraints or color figure charges

- Immediate publication on acceptance

- Inclusion in PubMed, CAS, Scopus and Google Scholar

- Research which is freely available for redistribution 